\title{
THE USE OF ELECTRONIC DEVICES BY STUDENTS, PARENTS AND TEACHERS BEFORE AND AFTER THE TRANSITION TO DISTANCE LEARNING
}

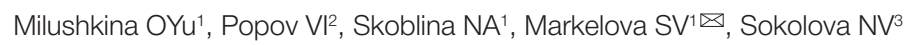

${ }_{1}$ Pirogov Russian National Research Medical University, Moscow, Russia

${ }^{2}$ Burdenko Voronezh State Medical University, Voronezh, Russia

${ }^{3}$ Voronezh State Pedagogical University, Voronezh, Russia

Transition to distance education in spring 2020 led to the overuse of information and communication technologies by the participants of the educational process. The aim of this study was to characterize the patterns of using electronic devices in high school students, their parents, and teachers in the settings of traditional brick-and-mortar education and distance learning. We created online questionnaires that were used to survey 200 high school students, 389 teachers and 251 parents before the transition to distance learning and also 658 teachers and 500 parents after the transition. Statistical analysis was conducted using Student's t test, $\chi^{2}$, and Pearson's contingency coefficient; relative risks were calculated using fourfold contingency tables. Differences were considered significant at $p \leq 0,05$. After the transition to distance learning, the number of electronic devices used by each student increased for $96.6 \%$ of the surveyed students; the average screen time also increased. About $80 \%$ of the surveyed parents reported that their children had more health complaints; of them, $60 \%$ reported symptoms typical of computer vision syndrome. We established a correlation between the readiness to cut down on screen time and the subjective assessment of vision as perfect or good by the respondents (Pearson's contingency coefficient $0.3 ; p \leq 0.05$ ). Our study confirms the relative risk for subjectively assessing one's vision as satisfactory or poor in individuals who use ED on a daily basis; the risk is 1.13 for students, 1.41 for parents, and 1.27 for teachers $(p \leq 0.05)$. The study proves that eliminating screen time from daily activities for at least one day per week is an effective measure for preventing vision disorders.

Keywords: students, teachers, parents, distance learning, health risk behavior, electronic devices, information and communication technologies

Author contribution: Milushkina OYu, Popov VI, Skoblina NA planned and supervised the study, analyzed the obtained data and wrote the manuscript; Markelova SV, Sokolova NV analyzed the literature, collected and processed the questionnaires. All authors participated in manuscript revision.

Compliance with ethical standards: the study was approved by the Ethics Committee of Pirogov Russian National Research Medical University (Protocol № 159 dated November 21, 2016). The survey did not encroach upon human rights, did not expose the respondents to any dangers and complied with the principles of biomedical ethics.

$\triangle$ Correspondence should be addressed: Svetlana V. Markelova

Ostrovityanova, 1, Moscow, 117997,Russia; markelova_sv@rsmu.ru

Received: 14.05.2020 Accepted: 15.06.2020 Published online: 28.06.2020

DOI: $10.24075 /$ brsmu.2020.037

\section{ИСПОЛЬЗОВАНИЕ ЭЛЕКТРОННЫХ УСТРОЙСТВ УЧАСТНИКАМИ ОБРАЗОВАТЕЛЬНОГО ПРОЦЕССА ПРИ ТРАДИЦИОННОЙ И ДИСТАНЦИОННОЙ ФОРМАХ ОБУЧЕНИЯ}

О. Ю. Милушкина', В. И. Попов², Н. А. Скоблина', С. В. Маркелова' $₫$, Н. В. Соколова ${ }^{3}$

${ }^{1}$ Российский национальный исследовательский медицинский университет имени Н. И. Пирогова, Москва, Россия

${ }^{2}$ Воронежский государственный медицинский университет имени Н. Н. Бурденко, Воронеж, Россия

${ }^{3}$ Воронежский государственный педагогический университет, Воронеж, Россия

\begin{abstract}
Внедрение дистанционного обучения весной 2020 г. привело к увеличению интенсивности использования информационно-коммуникационных технологий участниками образовательного процесса. Цель работы - дать гигиеническую характеристику использования электронных устройств школьниками, их родителями и учителями организаций общего образования в условиях различных режимов обучения (традиционного и дистанционного). В исследовании посредством онлайн-опроса приняли участие 200 школьников, 389 учителей и 251 родитель в период традиционного обучения, 658 учителей и 500 родителей - в период дистанционного обучения. При статистической обработке результатов использовали $t$-критерий Стьюдента, критерий $\chi^{2}$, коэффициент сопряженности Пирсона, относительный риск определяли с помощью четырехпольных таблиц сопряженности, $p \leq 0,05$. В период дистанционного обучения увеличились число используемых электронных устройств у 96,6\% школьников и время работы с ними. Увеличение числа жалоб на самочувствие учащихся отметили до 80\% родителей, из них более 60\% указывали на симптомы, характерные для компьютерно-зрительного синдрома. Установлена связь между возможностью отказа от использования электронного устройства и субъективной оценкой респондентами своего зрения как «отличное» и «хорошее» (КС Пирсона 0,3; $p \leq 0,05)$. Подтвержден риск субъективной оценки зрения как «удовлетворительное» и «Плохое» при ежедневном использовании электронного устройства: для школьников - 1,13, родителей - 1,41, учителей - 1,27 (p $\leq 0,05)$. Обоснован в качестве меры профилактики нарушения зрения отказ от использования электронного устройства минимум на один день в неделю.
\end{abstract}

Ключевые слова: школьники, учителя, родители, дистанционное обучение, поведенческие риски, электронные устройства, информационнокоммуникационные технологии

Вклад авторов: О. Ю. Милушкина, В. И. Попов, Н. А. Скоблина - планирование и научное руководство, обработка материала, написание статьи; С. В. Маркелова, Н. В. Соколова - анализ литературных данных, сбор и обработка материала. Все авторы - редактирование статьи.

Соблюдение этических стандартов: исследование одобрено этическим комитетом РНИМУ имени Н. И. Пирогова (протокол № 159 от 21 ноября 2016 г.) Проведение опроса не ущемляло права человека, не подвергало опасности респондентов, соответствовало требованиям биомедицинской этики.

$\bigotimes$ Для корреспонденции: Светлана Валерьевна Маркелова ул. Островитянова, д. 1, г. Москва, 117997; markelova_sv@rsmu.ru

Статья получена: 14.05.2020 Статья принята к печати: 15.06.2020 Опубликована онлайн: 28.06.2020

DOI: 10.24075/vrgmu.2020.037 
The regulatory framework for e-learning and distance education technologies was first captured in Russian legislation back in 2012 [1]. However, at that time teachers were not ready for the new teaching modalities, lacked knowledge of computer workstation ergonomics and safety, and did not fully understand the importance of good practices for safe computer use [2].

Nevertheless, information and communication technologies (ICT) have been gradually integrated into the educational process, and it is now hard to imagine education without computers, interactive digital boards, the Internet, or audio and video resources. Smartphones, tablets, and computers have become a vital part of daily lives of children, adolescents, and young adults. Today, there are about 10 million active Internet users below 14 years of age in Russia [2-6].

Because e-learning is a multifaceted educational challenge, some of its aspects are yet to be addressed, including workstation safety and ergonomics. New requirements for safe computer use imposed on education providers cannot solve the complexity of problems encountered in e-learning today [7-11].

The coronavirus pandemic of spring 2020 and the implemented containment measures dictated the need for transitioning from traditional brick-and-mortar education (TE) to distance learning (DL). This resulted in the overuse of ICT by all groups of the population, including students. The foreign literature on the transition from TE to DL discusses its economic implications, such as staff redundancy or saving costs, and learning outcomes (by comparing the results of final tests before and after the transition to DL), but do not mention the barrage of health complaints and the ways of preventing computer-associated damage to students' health [12-13].

The mass spread of electronic devices (ED) driven by the occupational and social necessity puts ED users at risk for various health conditions in a situation when good computer use practices are not followed. It is reported that young ED users suffer from increased emotional strain, irritability, sleep problems, and addiction [14-19]. The lack of physical activity and awkward static posture negatively affect the musculoskeletal, respiratory and cardiovascular systems, cause attention deficit and poor memory retention [20-23]. Poor image quality, wrong viewing distance, excessive or low lighting, and continuous screen time are all risk factors for vision disorders [24-27].

The high incidence of vision disorders witnessed over the past 15 years in children and adolescents has coincided with the mass spread of ED [28-29].

Increased use of ICT (stationary computers and portable devices) has resulted in high information load on students. Unfortunately, the existing screen time requirements are ignored [28].

Awareness should be raised about the possible detrimental impact of ED on the health of ED users, especially children; students should be taught skills allowing them to minimize the risk of ED-associated health problems in a situation when the teacher cannot control the ergonomics of their workstations. This means more responsibility on parents, who are expected to take proper care of their child's health and create the best environment for healthy $\mathrm{DL}$ from home.

So far, there have been no studies of health-related aspects of mass transition to DL in Russia.

The aim of this study was to characterize the patterns of using electronic devices in high school students, their parents, and teachers in the settings of traditional brick-and-mortar education and distance learning.

\section{METHODS}

Teachers working at the Department of Hygiene (Faculty of Pediatrics, Pirogov Russian National Research Medical University) and certified in hygiene education, hygiene of children and adolescents, and general hygiene designed 5 questionnaires and uploaded them to Google Forms. The sensitivity of the online vs. offline questionnaires was slightly below 82\% (Cl: 80.5-83.5); their specificity was at least 90\% (Cl: 88.1-92.2). The questionnaires for health assessment in the TE period were designed to target students, their parents and teachers (Appendix 1); the questionnaires for health assessment in the DL period were developed for parents and teachers only (Appendix 2). The following inclusion criteria were applied: being a high school student, a parent of a high school student or a high school teacher; the correctly filled out questionnaire form. Exclusion criteria: not being a high school student, a student's parent or a high school teacher; inability to correctly fill out the questionnaire form. The questionnaires contained 4 sections: background information, health complaints, questions about the patterns of using stationary and portable ED, questions about the skills necessary to safely use ED.

\section{Brick-and-mortar education, 2019}

Before the transition to distance learning, 200 high school students (grades 9-11) were surveyed from 8 Russian regions, including cities with over 1,000,000 residents; 43\% of them attended public schools with traditional curricula, the rest attended schools with advanced curricula, lyceums, etc.

Of 251 surveyed parents residing in 15 Russian regions, including cities with over $1,000,000$ population, the majority (86\%) were $30-49$ years old. Over $85 \%$ of them were women.

Of 389 teachers residing in 25 Russian regions, including cities with over 1,000,000 population, 31\% were 40-49 years of age. Over $90 \%$ of them were women.

\section{Distance learning, 2020}

In the DL period, 500 parents were surveyed from more than 15 Russian regions, including cities with over 1,000,000 residents. The majority of them (> 90\%) were women. The parent sample was dominated by individuals aged 30 to 49 years (89\%).

We also surveyed 658 teachers from over 30 Russian regions, including cities with a population of over 1,000,000.

Table 1. Subjective vision assessment and behavioral risk factors for ED overuse in high school students, their parents and teachers in the brick-and-mortar setting, \%

\begin{tabular}{|l|c|c|}
\hline \multicolumn{1}{|c|}{ Risk factor } & High school students & Parents \\
\hline No screen breaks & $64.5 \pm 3.4$ & $63.0 \pm 3.1$ \\
\hline Dim lighting & $87.0 \pm 2.4$ & $53.1 \pm 2.5^{\star}$ \\
\hline Wearing digital protecting lenses & $5.5 \pm 1.6$ & $7.5 \pm 2.1$ \\
\hline Subjective assessment of vision as satisfactory or poor & $49.0 \pm 3.0^{\star}$ & $51.4 \pm 3.2$ \\
\hline
\end{tabular}

Note: * differences are significant at $p \leq 0.05$. 
Table 2. Subjective vision assessment by high school students, parents and teachers who were willing or unwilling to reduce the amount of screen time, \%

\begin{tabular}{|l|c|c|}
\hline \multicolumn{1}{|c|}{ Reducing screen time } & High school students & Parents \\
\hline Not possible & $24.0 \pm 3.0$ & $41.8 \pm 3.1$ \\
\hline Can do without ED 1-3 days a week & $38.5 \pm 3.4$ & $33.1 \pm 3.0$ \\
\hline Can do without ED more than 3 days a week & $37.5 \pm 3.4$ & $47.8 \pm 2.5^{\star}$ \\
\hline Subjective vision assessment as perfect or good & $51.0 \pm 3.5$ & $25.1 \pm 2.7$ \\
\hline
\end{tabular}

Note: * differences are significant, $p \leq 0,05$.

The majority of them (> 85\%) were women. The most prevalent age group (32\%) was 40 to 49 years.

Statistical analysis was conducted in Statistica 13.0. (StatSoft Inc.; USA). The following statistics were used: Student's t test, $\chi^{2}$, Pearson's contingency coefficient. Relative risk $(R R$, i.e. the probability of a certain outcome depending on the environmental factor) was determined using fourfold contingency tables. Differences were considered significant at $p<0.05$.

\section{RESULTS}

In the TE period, the respondents were asked about their skills for safe ED use and measures they were possibly taking to prevent ICT-associated health damage.

Most high school students and their parents $(64.5 \%$ and $63.0 \%$, respectively) reported that they took screen breaks less often than once every hour; one in 6 teens $(17.0 \%)$ and one in 6 parents (17.5\%) did not take any breaks at all while using their ED (Table 1).

Of all the teachers surveyed in that period, over half of the respondents (53.1\%) took breaks less often than once every hour; one in 7 teachers (15.2\%) did not take any breaks at all (Table 1).

We established that only 1 in 8 students (13\%) and parents (12.7\%) preferred not to work on their ED if the lighting was dim, which is a standard ergonomics recommendation, whereas every third student (37\%) and every fifth parent (20.7\%) would continue using their device despite poor lighting conditions (Table 1).

One in 5 teachers (18.8\%) wrote that they would stop using $\mathrm{ED}$ if the lighting was poor, whereas one in 8 teachers (12.9\%) would continue using their ED (Table 1).

The majority of the surveyed teachers (86.6\%) think it necessary to promote healthy lifestyle in their students from early age. At the same time, $26.5 \%$ do not organize small screen breaks during the lesson and about half of the teachers (44.4\%) do not do eye exercises with their students, i.e. do not take measures aimed at maintaining their students' health, which is part of their professional duties. Interestingly, most teachers $(67.5 \%)$ report health problems in their students.

Half of the students (51\%) and half of the parents (48.6\%) assessed their vision as perfect $(24.5 \%$ and $19.5 \%$, respectively) or good (26.5\% and $29.1 \%$, respectively). One in 6 students (18.0\%) and one in 3 parents (31.5\%) said their vision was satisfactory; poor vision was reported by one in

3 students (31.0\%) and one in 5 parents (19.9\%). Perfect vision was reported by $10.7 \%$ of the teachers; good, by $29.9 \%$; satisfactory, by $46.0 \%$; and poor, by $13.4 \%$ (Table 1).

Only half of the students (49.0\%) said they did not need screen protection glasses; this percentage was consistent with the proportion of students who thought their vision was perfect or good. Only 5.5\% of the students said that they wore computer glasses when working on their computers, whereas others either denied wearing computer glasses or never used glasses at all (Table 1).

No need for vision correction was reported by $47.4 \%$ of the parents and $40.6 \%$ of the teachers. These figures were comparable to the proportion of adult respondents who thought their vision was perfect or good. Only $7.5 \%$ of the parents and $11.0 \%$ of the teachers wore computer glasses; others did not wear glasses although their vision acuity was poor, or wore glasses unsuitable for working with ED (like distance glasses) (Table 1).

Contingency tables revealed that about $50 \%$ of the surveyed students, parents and teachers did not pay due attention to their deteriorating vision or wore unsuitable glasses ( $p \leq 0.05)$.

Based on the survey results, we distributed the respondents into several groups depending on their readiness to reduce the amount of screen time (Table 2).

There were significant differences in the subjective assessment of vision acuity and the readiness to reduce the amount of screen time (having 1 or more days a week free of ED) between the teachers and parents ( $p \leq 0.05$ ) (Table 2).

Of all the students, parents and teachers who emphasized they could not do without ED, one-third $(37.5 \%, 38.1 \%$ and $36.0 \%$, respectively) subjectively assessed their vision as perfect or good; of those who could do without ED longer than 3 days, good or perfect vision was reported by a significantly higher number of respondents $(64.0 \%, 58.75 \%$ and $48.0 \%$, respectively; $p \leq 0.05$ ).

A correlation was established between the readiness to cut down on screen time and the subjective assessment of vision as perfect or good (Pearson's contingency coefficient equaled to $0.3 ; p \leq 0.05$ ).

During the DL period, significantly more students were using ED in their learning process (Table 3).

According to the parents, during the DL period screen time increased by $2 \mathrm{~h}$ for $15.0 \%$ of students, by $3 \mathrm{~h}$ for $20.8 \%$, by $4 \mathrm{~h}$ for $18.6 \%$, by $5 \mathrm{~h}$ for $10.0 \%$, and by $6 \mathrm{~h}$ for $25 \%$ of students.

Statistics generated by the Screen time app revealed that teachers used ED for $5.0 \pm 0.3 \mathrm{~h}$ on average in the TE period and for $8.0 \pm 0.3 \mathrm{~h}$ in the $\mathrm{DL}$ period $(p \leq 0.01)$.

Table 3. The proportion of high school students who used ED for traditional and distance education, according to parents' reports, \%

\begin{tabular}{|l|c|c|}
\hline \multicolumn{1}{|c|}{ Number of ED used for learning } & Traditional education & Distance learning \\
\hline No ED used & 36 & $3.4^{*}$ \\
\hline One ED & 47.4 & $29.8^{*}$ \\
\hline Two ED & 11.4 & $51.8^{*}$ \\
\hline Three of more ED & 5.2 & $15.0^{*}$ \\
\hline
\end{tabular}

Note: * - differences are significant, $p \leq 0,05$. 
The majority of the surveyed parents (80\%) reported that their children had more health complaints during the DL period. The complaints were grouped into a few categories based on their association with computer vision syndrome (eye fatigue $60.6 \%$, pain in the eyes $27.0 \%$, blurred vision $19.4 \%$, seeing dark spots $11.4 \%$, gritty eyes $16.2 \%)$, musculoskeletal disorders (back pain $37.6 \%$, neck pain $31.8 \%$ ), or psychoneurological disorders (headache $40.2 \%$, heavy head $21.0 \%$, muffled hearing or ringing in the ear $7.8 \%$, fatigue $58.0 \%$, psychoemotional strain $49.8 \%$, disrupted daily schedule, difficulty falling asleep $30.4 \%$ ). Only $17.2 \%$ of the students did not have any health complaints.

We calculated statistically significant relative risks for subjectively assessing one's vision as satisfactory or poor depending on the frequency of ED use (daily or with 1-3 day or longer breaks). In the respondents who used ED on a daily basis, the relative risk for subjectively assessing their vision as satisfactory or poor was 1.13 for students (Cl: 1.07-1.47); 1.41 for parents (Cl: 1.11-1.79), and 1.27 for teachers (Cl: 1.07-1.52).

\section{DISCUSSION}

ICT have been developing rapidly in the past 20 years and are now an indispensable part of our daily lives and education. The pandemic of spring 2020 compelled general education providers to transition to $\mathrm{DL}$.

It was demonstrated before the pandemic that only $0.5 \%$ of students did not have access to ED; the rest were using one to several ED on a daily basis. The amount of screen time was comparable between children and adults, varying from 7 to 10 $\mathrm{h}$ per day depending on age, sex, and season (school year/ holidays) [19, 25]. It is reported that screen time is rising [30].

In the DL period, the number of ED used by each student increased from 1 to 3 or more for almost all students (96.6\%) ( $p \leq 0.05$ ) (Table 3). Screen time increased from $2 \mathrm{~h}$ (15.0\% of students) to $6 \mathrm{~h}$ and more (25.0\%). As a result, the majority of parents (80\%) noticed that their children had more health complaints, most of which $(60 \%)$ were consistent with the clinical manifestations of computer vision syndrome, musculoskeletal disorders or psychoneurological problems.

Statistics generated by the Screen time app revealed that screen time had increased by $3 \mathrm{~h}$ a day in teachers in the DL period $(p \leq 0.01)$.

This is the result of ED overuse during quarantine and transition to DL, aggravated by the lack of digital technologies properly adapted to the educational process and the absence of specialized software. There are no clear criteria for the acceptable amount of screen time for different age groups in different seasons (holidays or school year); there are no transparent safety requirements for $E D$ image quality and technical specifications. The situation is further complicated by low awareness of workstation ergonomics and safety.

All groups of respondents heavily depended on their ED. One in 4 students $(24.0 \%)$, one in 2 parents $(41.8 \%)$ and one in 3 teachers (38.4\%) were not ready to cut down on their screen time (Table 2).

The surveys of teachers, students and parents conducted in the brick-and-mortar setting and after the transition to DL identified behavioral risk factors for ED overuse.

We found that the majority of the respondents did not follow the simple rules for minimizing computer-associated health damage: they did not take breaks every hour (64.5\% of students, $63.0 \%$ of parents, $53.1 \%$ of teachers), worked under poor lighting conditions (87.0\% of students, $87.3 \%$ of parents, $81.2 \%$, of teachers), had uncorrected vision problems, or wore unsuitable glasses (45.5\% of students, $44.8 \%$ of parents, $48.4 \%$ of teachers).

These risk factors for ED overuse were more frequent among parents than among teachers ( $p \leq 0.05)$; similarly, more parents than teachers characterized their vision as satisfactory or poor $(p \leq 0.05)$ (Table 1$)$.

Obviously, the family and the educational institution play a tremendous role in encouraging (or discouraging) students to develop a healthy and safe attitude to using ED. Our respondents demonstrated low awareness of this problem. This means that teachers, parents and students should be better educated in the health and safety issues relating to the use of ED. The expansion of distance learning, less control exerted by the teacher, and increased use of ICT by children outside the classroom demand that parents should have sufficient knowledge of good computer use practices.

The majority of teachers (67.5\%) report health problems in their students and realize the need to encourage students to lead a healthy lifestyle, which also means a healthy attitude to working with ED (86.6\%). At the same time, one-third of teachers $(26.5 \%)$ do not use short breaks during the lesson and one in 2 teachers (44.4\%) does not do eye exercises with their class. Perhaps, the teachers are not motivated to do so or simply do not have the time due to high curricular intensity.

Due to low awareness, 50\% of the respondents were not concerned with prophylaxis of computer-associated health problems or took ineffective measures like wearing unsuitable glasses $(p \leq 0.05)$.

Previously, we proved the risk of moderate or high myopia (RR 6.62) associated with| the frequency of using a laptop and a computer $(p \leq 0.05)$ [25].

The established correlation between the readiness of the participants to cut down on screen time and the subjective assessment of their vision as perfect or good suggests that vision disorders can be effectively prevented by limiting screen time. Respondents who were ready to eliminate ED from their daily activities for at least once a week assessed their vision as perfect or good significantly more often ( $p \leq 0.05$ ).

We discovered that there were significant relative risks for eye condition subjectively assessed as satisfactory or poor vision and associated with daily ED use; the RR values were 1.13 for children, 1.41 for parents, and 1.27 for teachers ( $p \leq 0.05)$.

Thus, we found that daily use of ED is a behavioral risk factor that can be modulated through implementing good computer use practices.

Based on our findings, we recommend that screen time should be strictly regulated or even eliminated from daily activities for at least one day per week. This will prevent the negative effects of ED in the traditional brick-and-mortar and distance learning settings. This approach will help to reduce the exposure to the negative factors and allow students to find time for physical activities or sports, thereby promoting a healthy lifestyle, improving the efficacy of prevention measures and eventually benefiting public health.

Once effective screen time guidelines are developed and the public becomes aware of how to use ED safely, one can expect an increase in the number of respondents with good skills for safe ED use.

\section{CONCLUSIONS}

1. We have identified behavioral risk factors for ICT overuse by students, teachers and parents after the transition to DL. Those include no screen breaks, poor lighting, uncorrected vision or 
unsuitable glasses, daily use of ED, prolonged screen time, using more than $1 \mathrm{ED}$ on a regular basis. 2. After the transition, the number of ED used by each student increased, screen time rose, and students had more health complaints. Teachers also used ED more, as compared to the TE period. 3. Due to the lack of skills for safe computer use, parents cannot be a role model for their children when it comes to a healthy attitude to ICT. 4. Eliminating screen time from daily activities for at least one day per week is an effective measure for preventing vision disorders. 5. The study provides rationale for expanding the scope of educational programs promoting healthy technology use in students, teachers and parents.

\section{References}

1. Federal'nyj zakon «Ob obrazovanii v Rossijskoj Federacii» \# 273 FZ ot 29.12.2012. Avialable from: http://www.consultant.ru/ document/cons_doc_LAW_140174/. Russian.

2. Kuchma VR. Deklaracija o gigienicheskoj bezopasnosti dlja detej i podrostkov cifrovoj sredy. Voprosy shkol'noj i universitetsko mediciny. 2014; 3: 62-63. Russian.

3. Kuchma VR, Suhareva LM, Hramcov PI. Gigienicheskaja bezopasnost' zhiznedejatel'nosti detej v cifrovoj srede. Zdorov'e naselenija i sreda obitanija. 2016; 8 (281): 4-7. Russian.

4. Buhtijarov IV, Denisov Jel, Eremin AL. Osnovy informacionno gigieny: koncepcii i problemy innovacij. Gigiena i sanitarija. 2014 93 (4): 5-9. Russian.

5. Bolshakov AM, Krutko VN, Kutepov EN, Mamikonova OA Potemkina NS, Rozenblit SI et al. Informational hygiene as a new topical branch of hygiene of children and adolescents. Gigiena sanitarija. 2016; 2: 172-7. Russian.

6. Sankov SV. Gigienicheskaja bezopasnost' jelektronno informacionno-obrazovatel'noj sredy $\vee$ sovremennoj shkole (nauchnyj obzor). Voprosy shkol'noj i universitetskoj mediciny zdorov'ja. 2018; 2: 13-20. Russian.

7. Koncepcija informacionnoj bezopasnosti detej. Rasporjazhenie pravitel'stva RF \# 2471-r (02 dekabrja 2015). Avialable from: http://static.government.ru/media/files/mPbAMyJ29uSPhL3p20 168GA6hv3CtBxD.pdf. Russian.

8. Janushanec OI, Petrova NA, Bezzubenkova EF, Neljubova EA Shirokova AJu. Gigienicheskaja ocenka tehnicheskogo osnashhenija realizacii informacionnyh tehnologij, ispol'zuemyh v obuchenii shkol'nikov. V sbornike: Profilakticheskaja medicina-2019: sbornik nauchnyh trudov Vserossijskoj nauchno-prakticheskoj konferencii s mezhdunarodnym uchastiem. 14-15 nojabrja 2019 goda. SPb.: Izd-vo SZGMU im. I. I. Mechniko-va, 2019: 244-50. Russian.

9. Kuchma VR, Suhareva LM, Hramcov PI. Sovremennye podhody k obespecheniju gigienicheskoj bezopasnosti zhiznedejatel'nosti detej $\vee$ giperinformacionnom obshhestve. Voprosy shkol'noj i universitetskoj mediciny i zdorov'ja. 2015; 3: 22-27. Russian.

10. Kuchma VR, Teksheva LM, Kurganskiy AM, Petrenko AO. Hygienic assessment of the use of readers in elementary school. Gigiena i sanitarija. 2014; 93 (3): 57-60. Russian.

11. Kuchma VR, Rapoport IK, Sokolova SB, Aleksandrova IYe, Makarova AYu, Mustafaeva KSh i dr. Rasprostranennost' i ocenka ispol'zovanija jelektronnyh ustrojstv $v$ uchebnoj i dosugovoj dejatel'nosti shkol'nikov 7-8 klassov. Sechenovskij vestnik. 2015 3 (21): 43-50. Russian

12. Laks M, Guerra SM, Miraglia JL, Medeiros EA. Distance Learning in Antimicrobial Stewardship: Innovation in Medical Education. PMID: 31174524; PMCID: PMC6555969; DOI: 10.1186/s12909019-1623-x. Russian.

13. Maria B, Oleksandr K, Valentina E, Olena Y. Distance-pedagogical technologies in olympic education for schoolchildren. Journal of Physical Education and Sport. Journal of Physical Education and Sport. 2019: 378 (4): 2497-503. Ukraine.

14. Druzhilov SA. Gigienicheskie aspekty informacionno-tehnologicheskoj zavisimosti cheloveka v novoj real'nosti. Gigiena i sanitarija. 2019; 98 (7): 748-53. Russian.

15. Smirnova AA, Sinogina ES. Vlijanie komp'jutera i seti internet na fizicheskoe i psihicheskoe zdorov'e shkol'nikov. Narodnoe obrazovanie. 2017; 1 (2): 199-204. Russian.

16. Kuchma VR, Tkachuk EA, Tarmaeva IYu. Psychophysiological state of children in conditions of informatization of their life activity and intensification of education. Gigiena i sanitarija. 2016; 12: 1183-8. Russian.

17. Lemola S, Perkinson-Gloor N, Brand S, Dewald-Kaufmann JF, Grob A. Adolescents' electronic media use at night, sleep disturbance, and depressive symptoms in the smartphone age. J Youth Adolesc. 2015; 44 (2): 405-18.

18. Shutova NV, Baranova YuM. Risk assessment of internet addiction for the mental health of adolescents. Gigiena i sanitarija. 2017; 96 (6): 568-72. Russian

19. Kuchma VR, Stepanova MI, Sazanyuk ZI, Polenova MA, Aleksandrova IE, Berezina NO, Makarova AYu. The hygienic estimation of training sessions using electronic tablet on functional state of students. Sechenov Medical Journal. 2015; 3 (21): 3542. Russian.

20. Rideout VJ, Foehr UG, Roberts DF. Generation M2: Media in the Lives of 8- to 18-Year-Old. Henry J. Kaiser Family Foundation, Menlo Park, California. 2010. Available from: http://www.kff.org/ entmedia/upload/8010.pdf

21. Pope-Ford R. Back flexion and extension: The effects of static posture on children using mobile devices. In: Advances in Intelligent Systems and Computing. AHFE International Conference on Safety Management and Human Factors, 2018; Orlando; United States; 21-25 July 2018. 2019; 791: 342-51.

22. Butuhanov VD. K voprosu valeologicheskih problem dvigatel'noj aktivnosti i zdorov'ja shkol'nikov. Bjulleten' Vostochno-Sibirskogo nauchnogo centra Sibirskogo otdelenija Rossijskoj akademii nauk. 2009; 2: 227-8. Russian.

23. Milushkina OYu, Skoblina NA, Markelova SV, Tatarinchik AA, Bokareva NA, Fedotov DM Assessing health risk for schoolchildren and students caused by exposure to educational and entertaining information technologies. Health Risk Analysis. 2019; 3: 135-43. Russian.

24. Wimalasundera S. Computer vision syndrome. Galle Medical. 2006; 11 (1): 201-4.

25. Skoblina NA, Milushkina OYu, Tatarinchik AA, Fedotov DM Tsameryan AP, Dobruk IV, et al. Hygienic problems of vision protection in schoolchildren and students in a hyper-information society. Russian ophthalmology of children. 2017; 4: 5-9. Russian.

26. Teksheva LM, Jelksnina EV, Perminov MA. Gigienicheskie aspekty ispol'zovanija komp'juternyh sredstv obuchenija $v$ sisteme obshhego obrazovanija. Gigiena i sanitarija. 2007; 4: 65-69. Russian.

27. Markelova SV. The role of printed and electronic publications in development of vision disorders. Fundamental and Clinical Medicine. 2019; 4 (4): 97-104. Russian.

28. Kuchma VR, Suhareva LM, Rapoport IK, Shubochkina EI, Skoblina NA, Milushkina OYu. Population health of the children, health risks, sanitary and epidemiological well-being of students: problems, solutions, technology activities. Gigiena i sanitarija. 2017; 96 (10): 990-5. Russian.

29. Zdravoohranenie $v$ Rossii 2017: statisticheskij sbornik. Rosstat. M., 2017. Available from: https://www.gks.ru/storage/mediabank/ zdrav17.pdf. Russian.

30. Lukyanec GN, Makarova LV, Paranicheva TM, Tyurina EV, Shibalova MS. Vlijanie gadzhetov na razvitie detej. Novye issledovanija. 2019; 1: 57: 25-35. Russian. 


\section{Литература}

1. Федеральный закон «Об образовании в Российской Федерации» № 273 ФЗ от 29.12.2012. Доступно по ссылке: http://www.consultant.ru/document/cons_doc_LAW_140174/.

2. Кучма В. Р. Декларация о гигиенической безопасности для детей и подростков цифровой среды. Вопросы школьной и университетской медицины. 2014; 3: 62-63.

3. Кучма В. Р., Сухарева Л. М., Храмцов П. И. Гигиеническая безопасность жизнедеятельности детей в цифровой среде. Здоровье населения и среда обитания. 2016; 8 (281): 4-7.

4. Бухтияров И. В., Денисов Э. И., Еремин А. Л. Основь информационной гигиены: концепции и проблемы инноваций. Гигиена и санитария. 2014; 93 (4): 5-9.

5. Большаков А. М., Крутько В. Н., Кутепов Е. Н., Мамиконова О. А., Потемкина Н. С., Розенблит С. И. и др. Информационные нагрузки как новый актуальный раздел гигиены детей и подростков. Гигиена и санитария. 2016; 2: 172-7.

6. Саньков С. В. Гигиеническая безопасность электронной информационно-образовательной среды в современной школе (научный обзор). Вопросы школьной и университетской медицины и здоровья. 2018; 2: 13-20.

7. Концепция информационной безопасности детей. Распоряжение правительства РФ № 2471-р (02 декабря 2015). Доступно по ссылке: http://static.government.ru/media/ files/mPbAMyJ29uSPhL3p20168GA6hv3CtBxD.pdf.

8. Янушанец О. И., Петрова Н. А., Беззубенкова Е. Ф., Нелюбова Е. А., Широкова А. Ю. Гигиеническая оценка технического оснащения реализации информационных технологий, используемых в обучении школьников. В сборнике: Профилактическая медицина-2019: сборник научных трудов Всероссийской научно-практической конференции с международным участием. 14-15 ноября 2019 года. СПб.: Изд-во СЗГМУ им. И. И. Мечнико-ва, 2019: 244-50.

9. Кучма В. Р., Сухарева Л. М., Храмцов П. И. Современные подходы К обеспечению гигиенической безопасности жизнедеятельности детей в гиперинформационном обществе. Вопросы школьной и университетской медицины и здоровья. 2015; 3: 22-27.

10. Кучма В. Р., Текшева Л. М., Курганский А. М., Петренко А. О. Гигиеническая оценка использования ридеров в начальной школе. Гигиена и санитария. 2014; 93 (3): 57-60.

11. Кучма В. Р., Рапопорт И. К., Соколова С. Б., Александрова И. Э., Макарова А. Ю., Мустафаева К.Ш. и др. Распространенность и оценка использования электронных устройств в учебной и досуговой деятельности школьников 7-8 классов. Сеченовский вестник. 2015; 3 (21): 43-50.

12. Laks M, Guerra CM, Miraglia JL, Medeiros EA. Distance Learning in Antimicrobial Stewardship: Innovation in Medical Education. PMID: 31174524; PMCID: PMC6555969; DOI: 10.1186/s12909019-1623-x.

13. Maria B, Oleksandr K, Valentina E, Olena Y. Distance-pedagogical technologies in olympic education for schoolchildren Journal of Physical Education and Sport. Journal of Physical Education and Sport. 2019; 378 (4): 2497-503. Ukraine.

14. Дружилов С. А. Гигиенические аспекты информационнотехнологической зависимости человека в новой реальности. Гигиена и санитария. 2019; 98 (7): 748-53.

15. Смирнова А. А., Синогина Е. С. Влияние компьютера и сети интернет на физическое и психическое здоровье школьников. Народное образование. 2017; 1 (2): 199-204.
16. Кучма В. Р., Ткачук Е. А., Тармаева И. Ю. Психофизиологическое состояние детей в условиях информатизации их жизнедеятельности и интенсификации образования. Гигиена и санитария. 2016; 12: 1183-8.

17. Lemola S, Perkinson-Gloor N, Brand S, Dewald-Kaufmann JF, Grob A. Adolescents' electronic media use at night, sleep disturbance, and depressive symptoms in the smartphone age. J Youth Adolesc. 2015; 44 (2): 405-18.

18. Шутова Н. В., Баранова Ю. М. Оценка риска интернетзависимости для психического здоровья подростков. Гигиена и санитария. 2017; 96 (6): 568-72.

19. Кучма В. Р., Степанова М. И., Сазанюк З. И., Поленова М. А., Александрова И. Э., Березина Н. О. и др. Гигиеническая оценка влияния учебных изданий с использованием электронных планшетов на функциональное состояние учащихся. Сеченовский вестник. 2015; 3 (21): 35-42.

20. Rideout VJ, Foehr UG, Roberts DF. Generation M2: Media in the Lives of 8- to 18-Year-Old. Henry J. Kaiser Family Foundation, Menlo Park, California. 2010. Available from: http://www.kff.org/ entmedia/upload/8010.pdf.

21. Pope-Ford R. Back flexion and extension: The effects of static posture on children using mobile devices. In: Advances in Intelligent Systems and Computing. AHFE International Conference on Safety Management and Human Factors, 2018; Orlando; United States; 21-25 July 2018. 2019; 791: 342-51.

22. Бутуханов В. Д. К вопросу валеологических проблем двигательной активности и здоровья школьников. Бюллетень Восточно-Сибирского научного центра Сибирского отделения Российской академии наук. 2009; 2: 227-8.

23. Милушкина О. Ю., Скоблина Н. А., Маркелова С. В., Татаринчик А. А., Бокарева Н. А., Федотов Д. М. Оценка рисков здоровью школьников и студентов при воздействии обучающих и досуговых информационно-коммуникационных технологий. Анализ риска здоровью. 2019; 3: 135-43.

24. Wimalasundera S. Computer vision syndrome. Galle Medical. 2006; 11 (1): 201-4.

25. Скоблина Н. А., Милушкина О. Ю., Татаринчик А. А., Федотов Д. М., Цамерян А. П., Добрук И. В. и др. Гигиенические проблемы охраны зрения школьников и студентов в условиях гиперинформационного общества. Российская детская остальмология. 2017; 4: 5-9.

26. Текшева Л. М., Элькснина Е. В., Перминов М. А. Гигиенические аспекты использования компьютерных средств обучения в системе общего образования. Гигиена и санитария. 2007; 4: 65-69.

27. Маркелова С. В. Роль печатных и электронных изданий в формировании функциональных нарушений и хронических заболеваний органа зрения обучающихся. Фундаментальная и клиническая медицина. 2019; 4 (4): 97-104.

28. Кучма В. Р., Сухарева Л. М., Рапопорт И. К., Шубочкина Е. И., Скоблина Н. А., Милушкина О. Ю. Популяционное здоровье детского населения, риски здоровью и санитарноэпидемиологическое благополучие обучающихся: проблемы, пути решения, технологии деятельности. Гигиена и санитария. 2017; 96 (10): 990-5.

29. Здравоохранение в России 2017: статистический сборник. Росстат. М., 2017. Доступно по ссылке: https://www.gks.ru/ storage/mediabank/zdrav17.pdf.

30. Лукьянец Г. Н., Макарова Л. В., Параничева Т. М., Тюрина Е. В., Шибалова М. С. Влияние гаджетов на развитие детей. Новые исследования. 2019; 1: 57: 25-35. 